Rhode Island College

Digital Commons @ RIC

Master's Theses, Dissertations, Graduate

Master's Theses, Dissertations, Graduate Research and Major Papers Overview Research and Major Papers

$7-22-2020$

\title{
Examining Knowledge of Pain Management
}

Sunita D. S. Dutt

Follow this and additional works at: https://digitalcommons.ric.edu/etd

Part of the Nursing Commons

\section{Recommended Citation}

Dutt, Sunita D. S., "Examining Knowledge of Pain Management" (2020). Master's Theses, Dissertations, Graduate Research and Major Papers Overview. 349.

https://digitalcommons.ric.edu/etd/349

This Major Paper is brought to you for free and open access by the Master's Theses, Dissertations, Graduate Research and Major Papers at Digital Commons @ RIC. It has been accepted for inclusion in Master's Theses, Dissertations, Graduate Research and Major Papers Overview by an authorized administrator of Digital Commons @ RIC. For more information, please contact digitalcommons@ric.edu. 


\title{
EXAMINING THE KNOWLEDGE AND ATTITUDES OF NURSES REGARDING PAIN MANAGEMENT
}

\author{
by
}

Sunita D.S. Dutt

A Major Paper Submitted in Partial Fulfillment

of the Requirements for the Degree of

Master of Science in Nursing

in

The School of Nursing

Rhode Island College

2020 


\section{Acknowledgements}

I would like to thank my family for all the support and time needed to fulfill the requirements for the MSN at Rhode Island College. It's been a long road and I am very much looking forward to this new career path. I would also like to thank my academic advisor Dr. Linda Dame, Dr. Lynn Blanchette, my $1^{\text {st }}$ reader, Dr. Debra Servello my $2^{\text {nd }}$ reader and Dr. Joanne Costello for their continued support and encouragement throughout this process. I would like to sincerely thank the librarian, Cheryl Banick at the Providence VA Medical Center for helping me find articles for this project. I would also like thank all my clinical preceptors \& faculty who allowed me to learn the knowledge and skills necessary for a future nurse practitioner. 


\section{Table of Contents}

Background/Statement of the Problem .......................................................... 1

Nursing Care and the Management of Pain................................................................. 3

The Joint Commission Guidelines.................................................4

Implementing the guidelines............................................... 5

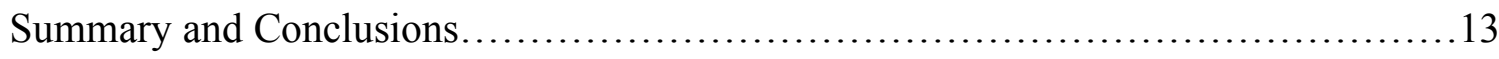

Recommendations and Implications for Advanced Nursing Practice..................14

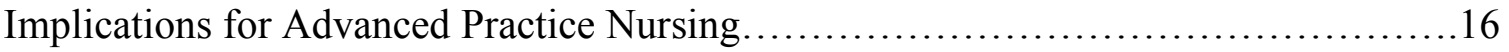

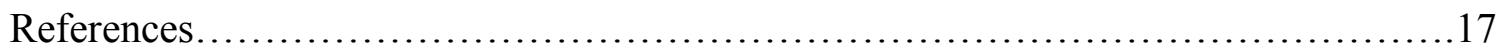




\section{Background/Statement of the Problem}

The prevalence of pain is rising among the adult American population and remains a major public issue throughout the world socially, economically and clinically. It affects approximately 100 million people, costing society $\$ 560-635$ billion per year (Chidgey \& Murphy, 2017). Imani \& Safari (2011), state that pain places a significant burden on the society and individuals through health care costs, loss of productivity, and loss of income. The International Association for the Study of Pain defines pain as an "unpleasant sensory and emotional experience associated with actual or potential tissue damage, or described in terms of tissue damage," (International Association for the Study of Pain, (2018).

Recent research studies have seen a widening gap between the increasing knowledge about pain and the application of nursing knowledge to treat pain (Imani \& Safari, 2011). Critically ill patients are particularly prone to pain, indicating a need for collective thinking and decision-making process among the healthcare professionals to genuinely manage their care. Fifty percent of Intensive Care Unit (ICU) patients experience moderate to severe pain, and ineffective pain management causes stress, anxiety, and suffering, which increases recovery times and decreases quality of life (Imani \& Safari, 2011). The prolonged length of stay in the ICU takes away patients' independence and places a huge financial burden on the health care system. In addition, ineffective pain management is believed to be linked to different cultural beliefs, politics, attitudes, educational levels and other logistic reasons held by the health care providers (Mossey, 2011). 
A collaborative effort among the healthcare providers, the institution of care and the patient is required to achieve optimum pain relief with appropriate professional interventions. However, a study by Salameh (2018) indicated that inadequate knowledge about pain management among critical care nurses exists and there are inconsistencies in their attitudes of practice. To meet this ethical responsibility of providing better pain management among critically ill patients, an advanced practice nurse should take up the leadership role of supporting nurses. Examples include, providing multi-modular pain management education and advocating for policies that help nurses to provide best patient care. Effective pain management through collaborative and inter-professional efforts with evidenced based guidelines will improve the quality of lives of patients experiencing pain as well as reduce the financial burdens for both the hospitals and patients. The Joint Commission (TJC) (2017), has published guidelines for use in acute care hospitals that can be used as a tool to better care of patients suffering from pain which should be part of the quality improvement programs. A nursing team, including advanced practice nurses should be part of this initiate, to implement and enforce the TJC guidelines through educational programs in their facilities and units. Implementing the TJC guidelines and setting standards of care using evidence based guidelines will increase knowledge of pain management among nurses and change their attitudes and prepare them to be strong advocates for their patients. 


\section{Nursing Care and the Management of Pain}

A continued pattern of lack of knowledge and attitudes of nurses and other healthcare professionals when caring for patients with pain is apparent. Studies suggest that there is a need for continued education and support for nurses and staff to better assess and provide high quality care for patients with pain, (Nuseir, Kassab, \& Almomani, 2016). The literature demonstrates the nursing staff use informal pain screening techniques and do not follow established screening techniques to assess pain using Numeric Rating Scale, NRS (0-10), (Shugarman, Asch, Rubenstein, \& Lorenz, 2010). Seventy-five percent of nurses reported knowing that the patient's own statement of pain is the most reliable indicator of pain assessment, but $50 \%$ reported believing that patients should endure pain before resorting to pain relief methods (Ucuzal \& Dogan, 2015). Nurse and healthcare provider misinformation about pain assessment techniques directly impacts patient recovery times (Al-Shaer, Hill and Anderson, 2011). Nursing education programs and continuing education training for nurses have not been kept up to date with the rapid expansion in scientific knowledge relating to pain management in pharmacology, technology, and complimentary therapy (Nuseir, Kassab, \& Almomani, 2016). Patients with opioid addiction have been found to not receive enough pain relief administered to them when they were experiencing severe pain (Duenas, Ojeda, Salazar, Mico, \& Failda, 2016). 


\section{The Joint Commission Guidelines}

The Joint Commission published guidance for hospitals for the assessment and management standards of pain in August of 2017 which has been in effect since January of 2018. The program is designed to strengthen organizational practices through a multilevel approach by strengthening the organizations' practices for pain assessment, treatment, education and monitoring which help healthcare professionals and clinicians to deliver safe and individualized care. The R3 or Requirement, Rationale and Reference report contains four areas for intervention which includes the leadership, medical staff, and performance improvement, provision of care, treatment and services (The Joint Commission, 2017). The new revised standards require hospitals to take up a leadership role in pain assessment and pain management, including safe opioid prescribing which should be an organizational priority for the hospital. Medical staff has a leadership role in organization performance improvement activities to improve quality of care, treatment, and services and patient safety. Through the provision of care, treatment, and services the hospitals are required to assess and manage the patient's pain and minimize the risks associated with treatment. The hospitals should also collect data to monitor their performance for performance improvement. Nurses, as providers of care and treatment, are also part of this intervention. Table 1 below shows evidence-based literature that comprises TJC Guidelines for pain management and how it could be implemented into the nursing practice. 
Table 1. Implementing the guidelines

Provision of Care, Treatment, and Services

\begin{tabular}{|c|c|c|}
\hline $\begin{array}{l}\text { Elements of Practice } \\
\text { Requirements }\end{array}$ & Evidence-Based Literature & $\begin{array}{l}\text { Implementation into Nursing } \\
\text { Care }\end{array}$ \\
\hline $\begin{array}{l}\text { EP 1: The hospital has } \\
\text { defined criteria to screen, } \\
\text { assess, and reassess pain that } \\
\text { are consistent with the } \\
\text { patient's age, condition, and } \\
\text { ability to understand. }\end{array}$ & $\begin{array}{l}\text { - Gelinas C, et al. Patients } \\
\text { and ICU Nurses' Perspective } \\
\text { of Non-Pharmacological } \\
\text { Interventions for Pain } \\
\text { Management. Nursing in } \\
\text { Critical Care, 2013; } \\
\text { 18(6):307-18. } \\
\text { - Vael A and Whitted K. An } \\
\text { Educational Intervention to } \\
\text { Improve Pain Assessment in } \\
\text { Preverbal Children. Pediatric } \\
\text { Nursing, 2014; 40(6):301-06. }\end{array}$ & $\begin{array}{l}\text { The organization should } \\
\text { provide clinicians and staff } \\
\text { with policies and guidelines to } \\
\text { use appropriate tools (e.g. } \\
\text { CPOT scale, numeric scale) to } \\
\text { assess and pain treat both acute } \\
\text { and chronic pain appropriate to } \\
\text { condition, age and ability to } \\
\text { understand. } \\
\text { The nursing staff should use the } \\
\text { appropriate tools and physical } \\
\text { evidence to assess and medicate } \\
\text { patients, followed by an } \\
\text { effectiveness assessment of the } \\
\text { treatment. } \\
\text { Data should be recorded in and } \\
\text { electronic flow record which } \\
\text { must show trends in pain } \\
\text { management and evaluation of } \\
\text { the treatment plan. } \\
\text { Collected data must be } \\
\text { analyzed by the } \\
\text { interdisciplinary team quarterly } \\
\text { which can be used to coordinate } \\
\text { education and training for staff. }\end{array}$ \\
\hline $\begin{array}{l}\text { EP 2: The hospital screens } \\
\text { patients for pain during }\end{array}$ & $\begin{array}{l}\text { McFarland DC, et al. } \\
\text { Predictors of Patient }\end{array}$ & $\begin{array}{l}\text { The Emergency room (ER) } \\
\text { initial assessment template }\end{array}$ \\
\hline
\end{tabular}




\begin{tabular}{|c|c|c|}
\hline $\begin{array}{l}\text { emergency department visits } \\
\text { and at the time of admission. }\end{array}$ & $\begin{array}{l}\text { Satisfaction with Inpatient } \\
\text { Hospital Pain Management } \\
\text { across the United States: A } \\
\text { National Study. Journal of } \\
\text { Hospital Medicine, 2016; } \\
\text { 11(7):498-501. } \\
\text { - Pierik JGJ, et al. Painful } \\
\text { Discrimination in the } \\
\text { Emergency Department: Risk } \\
\text { Factors for Underassessment } \\
\text { of Patient's Pain by Nurses. } \\
\text { Journal of Emergency } \\
\text { Nursing, 2017; 43(3):228- } \\
238 .\end{array}$ & $\begin{array}{l}\text { should prompt clinicians to } \\
\text { assess and document pain on } \\
\text { every patient. } \\
\text { Organizational support, annual } \\
\text { educational training and follow } \\
\text { up with quality assurance data } \\
\text { should be monitored by the } \\
\text { pain committee. } \\
\text { Strategies should be developed } \\
\text { that focuses on awareness } \\
\text { among nurses, of which } \\
\text { patients are at high risk for } \\
\text { underassessment of pain which } \\
\text { includes women, patients with } \\
\text { low education level, pre- } \\
\text { hospitalized patients on } \\
\text { analgesics, smokers and } \\
\text { anxious patients; this involves } \\
\text { providing nurses and clinicians } \\
\text { in the ER with better education } \\
\text { and understanding about pain, } \\
\text { use of appropriate tools and } \\
\text { drawing attention to patients } \\
\text { reported pain instead of making } \\
\text { assumptions. } \\
\text { Pain assessment outcomes } \\
\text { should be monitored through } \\
\text { feedback and audits by pain } \\
\text { experts, and clinicians should } \\
\text { be held accountable for the } \\
\text { noted deficits. }\end{array}$ \\
\hline $\begin{array}{l}\text { EP 3: The hospital treats the } \\
\text { patient's pain or refers the } \\
\text { patient for treatment. Note: } \\
\text { Treatment strategies for pain } \\
\text { may include }\end{array}$ & $\begin{array}{l}\text { Glowacki D. (2015). } \\
\text { Effective Pain Management } \\
\text { and Improvements in } \\
\text { Patients' Outcomes and }\end{array}$ & $\begin{array}{l}\text { Organizations need to develop } \\
\text { interdisciplinary pain teams can } \\
\text { lead to improvements in } \\
\text { patients' pain management, pair }\end{array}$ \\
\hline
\end{tabular}




\begin{tabular}{|c|c|c|}
\hline $\begin{array}{l}\text { Nonpharmacological, } \\
\text { Pharmacologic, or a } \\
\text { combination of approaches. }\end{array}$ & $\begin{array}{l}\text { Satisfaction. Critical Care } \\
\text { Nurse, 2015; 35(3):33-43. }\end{array}$ & $\begin{array}{l}\text { education, outcomes, and } \\
\text { satisfaction. } \\
\text { Policies should be developed } \\
\text { that guide pain management } \\
\text { with the use of both } \\
\text { pharmacological interventions } \\
\text { and non-pharmacological } \\
\text { interventions. } \\
\text { If pain is not adequately } \\
\text { managed by the treatment team, } \\
\text { they should refer the patient to } \\
\text { other pain management } \\
\text { specialists or services. } \\
\text { Patients who continue to have } \\
\text { some pain at discharge should } \\
\text { be provided with out-patient } \\
\text { referrals and resources in the } \\
\text { community to follow for } \\
\text { complete healing. }\end{array}$ \\
\hline $\begin{array}{l}\text { EP 4: The hospital develops a } \\
\text { pain treatment plan based on } \\
\text { evidence-based practices and } \\
\text { the patient's clinical } \\
\text { condition, past medical } \\
\text { history, and pain management } \\
\text { goals. }\end{array}$ & $\begin{array}{l}\text { - Moseley, G.L. \& Butler, } \\
\text { D.S. (2015) Fifteen Years of } \\
\text { Explaining Pain: The Past, } \\
\text { Present, and Future. The } \\
\text { Journal of Pain;16(9):807-13 } \\
\text { - Paschkis Z \& Potter ML. } \\
\text { (2015) Acute Pain } \\
\text { Management for Inpatients } \\
\text { with Opioid Use Disorder, } \\
\text { American Journal of Nursing, } \\
\text { 115(9):24-32; quiz 33, 46. } \\
\text { - Oliver J, et al. American } \\
\text { Society for Pain Management } \\
\text { Nursing Position Statement: } \\
\text { Pain Management in Patients } \\
\text { with Substance Use }\end{array}$ & $\begin{array}{l}\text { A comprehensive treatment } \\
\text { plan needs to be developed by } \\
\text { the multidisciplinary team that } \\
\text { is based on the best evidence } \\
\text { practice specific for the } \\
\text { patient's condition, past } \\
\text { medical history and treatment } \\
\text { goals. Clinical expertise should } \\
\text { be integrated with the best } \\
\text { research available to treat the } \\
\text { patient's reported type of pain } \\
\text { and not ignored based on self- } \\
\text { assumption. Physical } \\
\text { assessment and interventions } \\
\text { should be documented in the } \\
\text { patients EHR and bedside } \\
\text { nurses should follow up with }\end{array}$ \\
\hline
\end{tabular}




\begin{tabular}{|c|c|c|}
\hline & $\begin{array}{l}\text { Disorders. Journal of } \\
\text { Addictions Nursing, 2012; } \\
\text { 23(3):210-22. } \\
\text { - Schiavenato M and Craig } \\
\text { KD. Pain Assessment as a } \\
\text { Social Transaction: Beyond } \\
\text { the 'Gold Standard.' The } \\
\text { Clinical Journal of Pain, } \\
\text { 2010; 26(8):667-76. }\end{array}$ & $\begin{array}{l}\text { the effectiveness of the } \\
\text { treatment plan to provide safe } \\
\text { and quality pain relief. } \\
\text { Clinical nurse leaders and } \\
\text { APRNs need to take up the } \\
\text { leadership role to educate and } \\
\text { provide skills to manage } \\
\text { patients with different types of } \\
\text { pain. New policies need to be } \\
\text { developed and enforced. } \\
\text { The progress of the treatment } \\
\text { should be evaluated through } \\
\text { trends in historic data stored in } \\
\text { the easily assessable electronic } \\
\text { health record under pain } \\
\text { management tab. } \\
\text { The multimodular } \\
\text { biopsychological approach } \\
\text { should be used for pain rehab } \\
\text { with educational interventions } \\
\text { that decreases the } \\
\text { catastrophizing effect of pain. }\end{array}$ \\
\hline $\begin{array}{l}\text { EP 5: The hospital involves } \\
\text { patients in the pain } \\
\text { management treatment } \\
\text { planning process through the } \\
\text { following: } \\
\text { - Developing realistic } \\
\text { expectations and measurable } \\
\text { goals that are understood by } \\
\text { the patient for the degree, } \\
\text { duration, and reduction of } \\
\text { pain } \\
\text { - Discussing the objectives } \\
\text { used to evaluate treatment }\end{array}$ & $\begin{array}{l}\text { - Moseley GL and Butler DS. } \\
\text { Fifteen Years of Explaining } \\
\text { Pain: The Past, Present, and } \\
\text { Future. The Journal of Pain, } \\
\text { 2015;16(9):807-13 } \\
\text { - Paschkis Z and Potter ML. } \\
\text { Acute Pain Management for } \\
\text { Inpatients with Opioid Use } \\
\text { Disorder, American Journal } \\
\text { of Nursing, 2015; 115(9):24- } \\
\text { 32; quiz 33, 46. } \\
\text { - Oliver J, et al. American } \\
\text { Society for Pain Management }\end{array}$ & $\begin{array}{l}\text { The treatment team should } \\
\text { always include patient in the } \\
\text { planning and treatment process } \\
\text { to establish goals that are } \\
\text { realistic and measurable; the } \\
\text { plan should be well explained } \\
\text { to the patient by the providers } \\
\text { in terms they understand and } \\
\text { accept. Clinicians should meet } \\
\text { together as a team to educate } \\
\text { the patient about the type of } \\
\text { pain they experiencing and the } \\
\text { treatment options and side } \\
\text { effects; assessment of pain }\end{array}$ \\
\hline
\end{tabular}




\begin{tabular}{|c|c|c|}
\hline $\begin{array}{l}\text { progress (for example, relief } \\
\text { of pain and improved } \\
\text { physical and psychosocial } \\
\text { function) } \\
\text { - Providing education on pain } \\
\text { management, treatment } \\
\text { options, and safe use of } \\
\text { opioid and non-opioid } \\
\text { medications when prescribed. }\end{array}$ & $\begin{array}{l}\text { Nursing Position Statement: } \\
\text { Pain Management in Patients } \\
\text { with Substance Use } \\
\text { Disorders. Journal of } \\
\text { Addictions Nursing, 2012; } \\
\text { 23(3):210-22. } \\
\text { - Schiavenato M and Craig } \\
\text { KD. Pain Assessment as a } \\
\text { Social Transaction: Beyond } \\
\text { the 'Gold Standard.' The } \\
\text { Clinical Journal of Pain, } \\
\text { 2010; 26(8):667-76. }\end{array}$ & 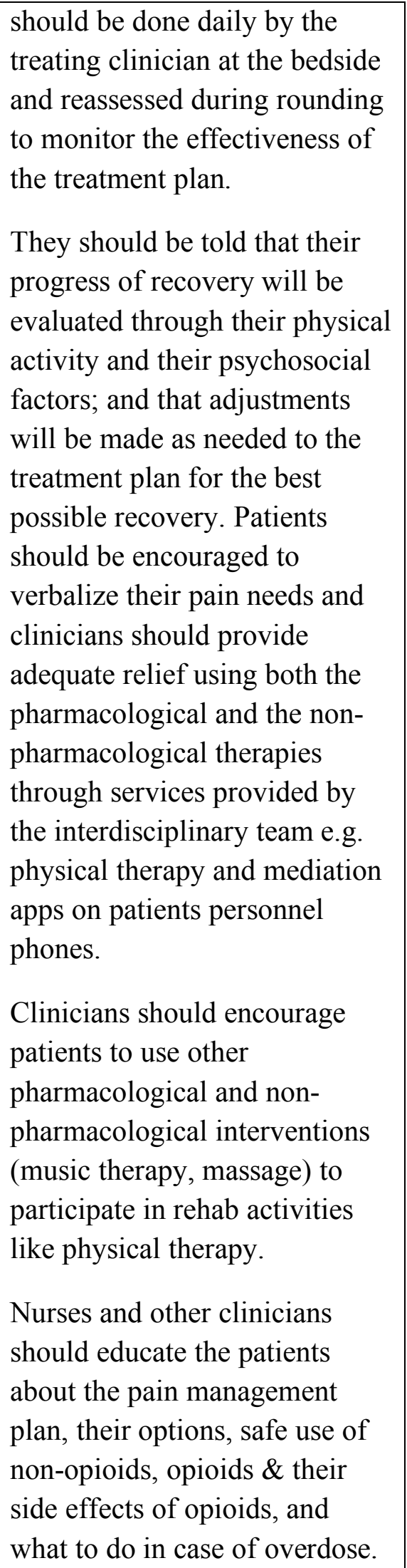 \\
\hline
\end{tabular}




\begin{tabular}{|c|c|c|}
\hline $\begin{array}{l}\text { EP 6: The hospital monitors } \\
\text { patients identified as being } \\
\text { high risk for adverse } \\
\text { outcomes related to opioid } \\
\text { treatment. }\end{array}$ & $\begin{array}{l}\text { TJC. Safe use of opioids in } \\
\text { hospitals. Sentinel Event } \\
\text { Alert; 2012; } 49 . \\
\text { • Frederickson TW, et al. } \\
\text { Reducing Adverse Drug } \\
\text { Events Related to Opioids } \\
\text { Implementation Guide. } \\
\text { Philadelphia: Society of } \\
\text { Hospital Medicine, 2015. } \\
\text { - Jarzyna D, et al. American } \\
\text { Society for Pain Management } \\
\text { Nursing Guidelines on } \\
\text { Monitoring for Opioid- } \\
\text { Induced Sedation and } \\
\text { Respiratory Depression. Pain } \\
\text { Management Nursing: } \\
\text { Official Journal of the } \\
\text { American Society of Pain } \\
\text { Management Nurses, } \\
\text { American Society for Pain } \\
\text { Management Nursing, 2011; } \\
\text { 12(3):118-45. }\end{array}$ & $\begin{array}{l}\text { The close monitoring of } \\
\text { patients who are at greatest risk } \\
\text { for misuse of their prescribed } \\
\text { medication should contain a } \\
\text { treatment protocol which is } \\
\text { embedded in the EHR that } \\
\text { includes an opioid agreement, } \\
\text { regular urine toxicology } \\
\text { screens, compliance checklists, } \\
\text { labs, pill counts, and, if } \\
\text { indicated, motivational } \\
\text { counseling. (Jamison, } \\
\text { Serraillier, \& Michna, 2011). }\end{array}$ \\
\hline $\begin{array}{l}\text { EP 7: The hospital reassesses } \\
\text { and responds to the patient's } \\
\text { pain through the following: } \\
\text { - Evaluation and } \\
\text { documentation of response(s) } \\
\text { to pain intervention(s) } \\
\text { - Progress toward pain } \\
\text { management goals including } \\
\text { functional ability (for } \\
\text { example, ability to take a } \\
\text { deep breath, turn in bed, and }\end{array}$ & $\begin{array}{l}\text { Ballantyne JC and Sullivan } \\
\text { MD. Intensity of Chronic } \\
\text { Pain - The Wrong Metric? } \\
\text { The New England Journal of } \\
\text { Medicine, 2015; } 373 \\
\text { (22):2098-99. }\end{array}$ & $\begin{array}{l}\text { Written hospital policies and } \\
\text { protocols should elaborate the } \\
\text { traditional numeric rating scale } \\
\text { to include functional goal. All } \\
\text { interventions should be } \\
\text { frequently evaluated and } \\
\text { patient's progress towards } \\
\text { recovery monitored. } \\
\text { It should be a team effort to } \\
\text { monitor the patient's progress } \\
\text { through constant physical } \\
\text { observation and reviewing the }\end{array}$ \\
\hline
\end{tabular}




\begin{tabular}{|c|c|c|}
\hline $\begin{array}{l}\text { EP 8: The hospital educates } \\
\text { the patient and family on } \\
\text { discharge plans related to } \\
\text { pain management including } \\
\text { the following: } \\
\text { - Pain management plan of } \\
\text { care } \\
\text { - Side effects of pain } \\
\text { management treatment } \\
\text { - Activities of daily living, } \\
\text { including the home } \\
\text { environment, that might } \\
\text { exacerbate pain or reduce } \\
\text { effectiveness of the pain } \\
\text { management plan of care, as }\end{array}$ & $\begin{array}{l}\text { Glowacki D. (2015). } \\
\text { Effective Pain Management } \\
\text { and Improvements in } \\
\text { Patients' Outcomes and } \\
\text { Satisfaction. Critical Care } \\
\text { Nurse;35(3):33-43. } \\
\text { - Jack BW, et al. A } \\
\text { Reengineered Hospital } \\
\text { Discharge Program to } \\
\text { Decrease Re-hospitalization: } \\
\text { A Randomized Trial. Annals } \\
\text { of Internal Medicine, 2009; } \\
\text { 150(3):178-87. }\end{array}$ & $\begin{array}{l}\text { effects of the therapies } \\
\text { provided. Continued education } \\
\text { and support for nurses and } \\
\text { other clinicians should be } \\
\text { provided to decrease suffering } \\
\text { and faster healing. } \\
\text { Data analysis should be } \\
\text { collected quarterly and } \\
\text { evaluated by the members of } \\
\text { the pain committee for } \\
\text { effectiveness as well as the side } \\
\text { effects of the treatment by } \\
\text { tracking adverse events by } \\
\text { running end of shift pain } \\
\text { effectiveness report; pain } \\
\text { effectiveness report should } \\
\text { include both the pre-assessment } \\
\text { of pain and post assessment } \\
\text { after treatment. Plan should be } \\
\text { revised to provide safe and } \\
\text { quality care. } \\
\text { appointments. Patient should be } \\
\text { given information about the } \\
\text { The treating team must educate } \\
\text { the patients and their families } \\
\text { about the diagnosis, the pain } \\
\text { treatment plan of care and side } \\
\text { effects of medications } \\
\text { throughout the hospitalization } \\
\text { and at discharge. } \\
\text { Interdisciplinary team } \\
\text { involvement from the } \\
\text { admission to discharge helps } \\
\text { patient focus on goals of care } \\
\text { and recovery. } \\
\text { thinst coordinate and } \\
\text { their follow up }\end{array}$ \\
\hline
\end{tabular}




\begin{tabular}{|l|l|l|}
\hline $\begin{array}{l}\text { well as strategies to address } \\
\text { these issues }\end{array}$ & $\begin{array}{l}\text { appointment location, transport } \\
\text { and when and how to get their } \\
\text { disposal of opioids when } \\
\text { prescribed. }\end{array}$ & $\begin{array}{l}\text { Medication reconciliation } \\
\text { should be completed following } \\
\text { the national guidelines by } \\
\text { clinicians. Any changes to } \\
\text { medications should be reviewed } \\
\text { with patient, which should } \\
\text { consist of the purpose of the } \\
\text { medication, appropriately route } \\
\text { administration and its side } \\
\text { effects. Safe use, storage and } \\
\text { disposal of opioids when } \\
\text { prescribed should be discussed. } \\
\text { Discharging clinician should be } \\
\text { provide the patient with contact } \\
\text { information for the primary } \\
\text { care clinician with their phone } \\
\text { numbers for weekends, } \\
\text { evenings, and holidays. } \\
\text { Education to patients should } \\
\text { constitute an emergency } \\
\text { situation and what they should } \\
\text { do in case of emergency or side } \\
\text { effects of medications. }\end{array}$ \\
\hline
\end{tabular}




\section{Summary and Conclusions}

TJC guidelines are utilized for best practice identification using current evidence to provide guidance for acute care facility policy and nursing education. Dissemination of best practice for the provision of care, treatment, and services to nursing and other healthcare providers is critical to promoting positive patient outcomes. Evidence exists to identify pain and to offer appropriate treatment. Acute care facilities must make improving pain management a priority and assign resources to achieve this outcome. A collaborative effort among the healthcare providers and the patient is required to achieve optimum pain relief with appropriate professional interventions. 


\section{Recommendations and Implications for Advanced Nursing Practice}

Every patient has a right to appropriate pain relief, including those with the history of opioid use disorder. The Joint Commission provides guidelines to provide effective and individualized care for patients experiencing pain. It is apparent that the field of nursing lags behind in pain management education and as a result nurses either do not adequately treat their patients or have attitudes towards some high risk patients e.g. women, patients with low education, pre-hospitalized patients with analgesia use, smokers and anxious patients. To grow and advance our professional with new technology and medicine in pain management Advanced Practice should take up leadership roles in their institutions to educate nurses and develop policies and procedures so that nurses could provide effective pain management with confidence. Nurses should not rely on their own assessments and have their cultural biases towards patients suffering from pain but use appropriate tools e.g. numeric rating scale and functional scales to better understand the patients' pain. Another very important intervention is using the biopsychological means to explain pain to patient so that patient focuses on the biological aspect of healing rather than the psychological view point. Active listening, empathizing, showing respect have shown positive outcomes from patients participating in the treatment plan. Treatment plan should always is realistic and measurable and nurses should be advocates for their patients in the healing process. No stigma or misconceptions should be held against any patient as we focus to provide compassionate and holistic care involving both the pharmacological and nonpharmacological methods. Pre and post pain rating scale documentation in the electronic medical record and analysis of data regarding the treatment plan. Pain 
management involves team collaboration and interdisciplinary team effort to assist the patient back to their highest level of functioning from admission to discharge and outpatient follow up. 


\section{Implications for Advanced Practice Nursing}

Advanced practice nurses have a critical role in education, policy, and research to transform pain management practices and to evaluate the effectiveness of the programs that comply with TJC guidelines. They have the potential to be a significant resource and support for nurse and healthcare professional colleagues. APRN's can collaborate with other members of the multidisciplinary team and provide strategies that promote positive patient outcomes, using knowledge sharing, respectful negotiation, and promoting inter-professional nurse driven care. APRN's can promote pain management which will result in cost effective, patient centered care for their patients, meeting the behavioral, psychosocial, cultural, and spiritual needs of their patients. As a result the role of the APRN can transform the healthcare system to be more accessible to patients with pain for quality, safe, and value driven care. 


\section{References}

Al-Shaer, D., Hill, P. D., \& Anderson, M. A. (2011). Nurses' knowledge and attitudes regarding pain assessment and intervention. MedSurg Nursing, 20(1), 7-10.

Ballantyne, J. C., \& Sullivan, M. D. (2015). Intensity of Chronic Pain--The Wrong Metric?. The New England journal of medicine, (373)22, 2098-2099. https://doi.org/10.1056/NEJMp1507136

Chidney, B. A., \& Murphy, B. A. (2017, September, 22). Evidence-based medicine and regulatory oversight: opioid prescribing for treatment of pain. North Carolina Medical Journal, 78(5), 310-311. doi:10.18043/ncm.78.5.310

Duenas, M., Ojeda, B., Salazar, A., Mico, J., \& Failda, I. (2016). A review of chronic pain impact on patients, their social environment and the health care system. Journal of Pain Research, 2016(9). doi:10.2147/JPR.S105892

Gelinas, C., Arbour, C., Michaud, C., Robar, L., \& Cote, J. (October, $3^{\text {rd }}$, 2012). Patients and ICU nurses' perspectives of non-pharmacological interventions for pain management. British Association of Critical Care Nursing

Glowacki D. (2015). Effective pain management and improvements in patients' outcomes and satisfaction. Critical care nurse, 35(3), 33-43.

https://doi.org/10.4037/ccn2015440

IASP Terminology. (2018). Retrieved from https://www.iasp pain.org/Education/Content.aspx?ItemNumber $=1698$

Imani, F., \& Safari, S. (2011). "Pain relief is an essential human right", We should be concerned about it". Anesthesiology and Pain Medicine, 9(4). doi:10.5812/kowsar.22287523.2306 
Jack, B. W., Chetty, V. K., Anthony, D., Greenwald, J. L., Sanchez, G. M., Johnson, A. E., Forsythe, S. R., O'Donnell, J. K., Paasche-Orlow, M. K., Manasseh, C., Martin, S., \& Culpepper, L. (2009). A reengineered hospital discharge program to decrease re-hospitalization: a randomized trial. Annals of internal medicine, 150(3), 178-187. https://doi.org/10.7326/0003-4819-150-3200902030-00007

Jarzyna, D., Jungquist, C. R., Pasero, C., Willens, J. S., Nisbet, A., Oakes, L., Dempsey, S. J., Santangelo, D., \& Polomano, R. C. (2011). American Society for Pain Management Nursing guidelines on monitoring for opioid-induced sedation and respiratory depression. Pain management nursing: Official Journal of the American Society of Pain Management Nurses, 12(3), 118-145.e10. https://doi.org/10.1016/j.pmn.2011.06.008

McFarland, D., Shen, M., Holcombe, R. (July, 2016). Predictors of patient satisfaction with inpatient hospital pain management across the United States: A national survey. Journal of Hospital Medicine, 11 (7), 498-501. Retrieved from https://mdedge-files-live.s3.us-east-2.amazonaws.com/files/s3fspublic/pdfs/journals/jhm2576.pdf

Mossey, J. (2011, July, 2011). Defining racial and ethnic disparities in pain management. Clinical Orthopedics and Related Research, 469(7), 1859-1870. https://doi.org/10.1007/s11999-011-1770-9

Nuseir, K., Kassab, M., \& Almomani, B. (2016). Healthcare providers' knowledge and current practice of pain assessment and management: How much progress have 
we made? Pain Research and Management, 2016. doi:10.1155/2016/8432973

Oliver, J., Coggins, C., Compton, P., Hagan, S., Matteliano, D., Stanton, M., St Marie, B., Strobbe, S., \& Turner, H. N. (2012). American Society for Pain Management nursing position statement: pain management in patients with substance use disorders. Pain management nursing: official journal of the American Society of Pain Management Nurses, 13(3), 169-183. https://doi.org/10.1016/j.pmn.2012.07.001

Paschkis Z, Potter ML. CE: Acute Pain Management for Inpatients with Opioid Use Disorder. The American Journal of Nursing. 2015 Sep; 115(9):24-32; quiz 33, 46. doi:10.1097/01.naj.0000471243.30951.92.

Pierik JGJ, IJzerman MJ, Gaakeer MI, Vollenbroek-Hutten MMR, Doggen CJM. Painful Discrimination in the Emergency Department: Risk Factors for Underassessment of Patients' Pain by Nurses. J Emerg Nurs. 2017;43(3):228-238. doi:10.1016/j.jen.2016.10.007

R3 Report. Requirement, Rationale, Reference. (2017). Retrieved from https://www.jointcommission.org/-/media/tjc/documents/standards/r3reports/r3_report_issue_11_2_11_19_rev.pdf

Safe use of opioids in hospitals. (2012). Retrieved from https://www.jointcommission.org/-/media/deprecated-unorganized/importedassets/tjc/system-folders/topicslibrary/sea_49_opioids_8_2_12_finalpdf.pdf?db=web\&hash=0135F306FCB10D9 19CF7572ECCC65C84

Salameh, B. (2018). Nurses' knowledge regarding pain management in high acuity care 
units: A case study of Palestine. International Journal of Health Sciences, $12(3), 51-57$.

Schiavenato, Martin, and Kenneth D. Craig. "Pain Assessment as a Social Transaction: Beyond the "gold Standard". Clinical Journal of Pain, (26)8, 2010, pp. 667-76. Shugarman, L. R., Asch, S. M., Rubenstein, L. V., \& Lorenz, K. A. (2010). Nursing staff, patient and environment factors associated with accurate pain assessment. Journal of Pain and Symptom Management, 40(5), 723733.doi:10.1016/j.jpainsymman.2010.02.024

Society of Hospital Medicine, (2016). Frederickson TW; Gordon DB; De Pinto M; Kral LA; Furnish T; Gupta R; Austin PN.

Ucuzal, M., \& Dogan, R. (2015). Emergency nurses' knowledge, attitude and clinical decision making skills about pain. International Emergency Nursing, 23(2), 7580. Retrieved from doi.org/10.1016/j.ienj.2014.11.006

Vael A, Whitted K. An educational intervention to improve pain assessment in preverbal children. Pediatric Nursing. 2014 Nov-Dec;40(6):302-6, 301. 
